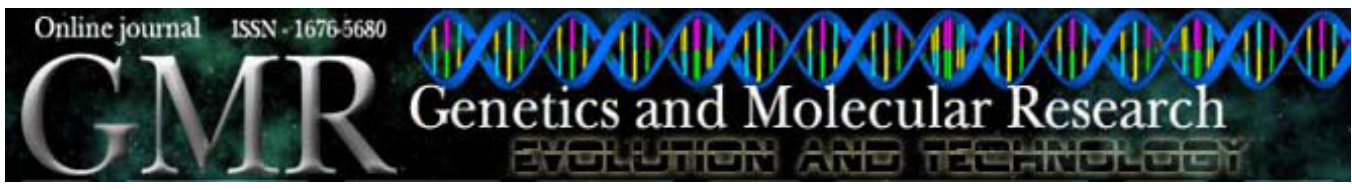

\title{
Molecular marker-assisted selection of the ae alleles in maize
}

\author{
F. Chen, S.W. Zhu, Y. Xiang, H.Y. Jiang and B.J. Cheng \\ Life Science College, Anhui Agricultural University, China \\ Corresponding author: B.J. Cheng \\ E-mail: beijiucheng@ahau.edu.cn
}

Genet. Mol. Res. 9 (2): 1074-1084 (2010)

Received February 21, 2010

Accepted March 19, 2010

Published June 11, 2010

DOI 10.4238/vol9-2gmr799

\begin{abstract}
The ae (amylose extender) recessive mutant alleles in maize are an important genetic resource for the development of highamylose cultivars. On the basis of ae allele sequences (from the National Center for Biotechnology Information), the ae mutant alleles were cloned from high-amylose maize and the allelic $A e$ gene from common maize luyuan92 inbred lines. Five pairs of primers were designed to screen for a molecular marker of ae alleles, yielding a dominant molecular marker, ae474. We used 53 types of high-amylose maize and common maize inbred lines and their hybrid and backcross offspring for verification and analysis. The ae dominant molecular marker was effective in selecting for the ae alleles and for biological materials with a high-amylose genotype. Presence and absence of the marker in the offspring conformed to the expected Mendelian ratios. Using this marker, we were able to detect the ae alleles in a backcross and its second generation more efficiently (53.3 and $73.3 \%$, respectively) than was possible without marker selection. These data indicate that the marker can be used as a tool to improve selection efficiency and accelerate the cultivation of new varieties of high-amylose maize.
\end{abstract}

Key words: Maize; Starch branching enzyme; High amylase; Marker-assisted selection 


\section{INTRODUCTION}

Maize grain is high in starch, amounting to $70 \%$ of the total weight of grain (Wu et al., 2009). Common maize starch is a mixture of approximately $28 \%$ amylose and $72 \%$ amylopectin. There are a large number of industrial uses for amylose, including food, medicines, textiles, paper, and environmental protection (Rutenberg and Solarek, 1984; Smith et al., 1997; Sun et al., 1998; Nishi et al., 2001; Seetharaman et al., 2001; Leterrier et al., 2008).

Separation of high-quality amylose from common maize is expensive, thus limiting its industrial use and significantly influencing the cost of products. Although most high-amylose maize production occurs in the United States, the actual amount cultivated in the US is low (Whistler, 1958; Fergason, 1994). Because of the substantial commercial demand for amylose, the development of high-amylose maize cultivars is an important research goal. Discovery of the $a e$ (amylose extender) mutant alleles was a very important step in developing high-amylose plants. Amylose content is much higher in maize endosperm possessing the ae alleles, which are single recessive endosperm mutant alleles (Fisher et al., 1996; Kim et al., 1998). Wu et al. (2009) found that the amylose content of a maize ae homozygote, possessing the modified gene, was elevated by $50-80 \%$, relative to a cultivar without the modified gene.

The traditional method of cultivating high-amylose maize cultivars is screening by phenotypic selection using backcross and alternate selfing, such that a backcross can be acquired every two generations. The method, however, is inefficient and the breeding cycle is long. The development of a stable molecular marker for the ae alleles would facilitate the identification of promising phenotypes and would accelerate the breeding of high-amylose cultivars. The goal of this study was to clone the $a e$ and $A e$ alleles in maize, to analyze their sequences and to develop an ae allele molecular marker. We studied the characteristics and reliability of the $a e$ alleles and analyzed the effect and efficiency of molecular marker-assisted selection in a high-amylose phenotype backcross.

\section{MATERIAL AND METHODS}

\section{Maize and bacterial supplies}

Fifty-three test lines, including 38 inbred lines (14 high-amylose maize inbred lines with the ae alleles and 24 common maize inbred lines), were used. Among them, high-amylose maize inbred lines, ae-1 and ae-2, were introduced from the US, and W64, B37, A619, and W23 were purchased from the market. The remaining lines were bred and maintained in the laboratory. We used 15 kinds of combination groups of high-amylose maize and common maize, derived from three initial crossings: $\mathrm{We}_{-4-2} \times$ chang98, B37 x qi478, and $\mathrm{S}_{4-25-2-1} \mathrm{x}$ chang72. In each group, with chang98, qi478 and chang72 as recurrent parents, we were able to obtain seven groups: $\mathrm{F}_{1}, \mathrm{~F}_{2}, \mathrm{BC}_{1} \mathrm{~F}_{1}, \mathrm{BC}_{1} \mathrm{~F}_{2}, \mathrm{BC}_{2} \mathrm{~F}_{1}, \mathrm{BC}_{2} \mathrm{~F}_{2}$, and $\mathrm{BC}_{3} \mathrm{~F}_{1}$, each constructed in our laboratory. We used Escherichia coli DH5a, a standard strain maintained in our laboratory.

\section{DNA extraction}

We extracted genomic DNA from maize leaves using the CTAB method described by Saghai Maroof et al. (1994). To extract genomic DNA from half seeds, the endosperms were 
first removed and then crushed in $200 \mu \mathrm{L}$ chloroform in a $1.5-\mathrm{mL}$ tube. The crushed samples were mixed with $300 \mu \mathrm{L}$ DNA extraction liquid (100 mM Tris-HCl, $100 \mathrm{mM}$ EDTA-Na $\mathrm{Na}_{2}, 500$ $\mathrm{mM} \mathrm{NaCl}, 1.5 \% \mathrm{SDS}$ ), followed by centrifugation at $12,000 \mathrm{rpm}$ for $2 \mathrm{~min}$ at room temperature. The supernatant was transferred to a $1.5-\mathrm{mL}$ tube with $500 \mu \mathrm{L}$ cold isopropanol to precipitate the DNA. To further concentrate the DNA, the solution was centrifuged at 12,000 rpm for $2 \mathrm{~min}$. The resulting supernatant was discarded and the pellet dried at room temperature before being dissolved in $200 \mu \mathrm{L}$ TE buffer. DNA quality was confirmed by electrophoresis and UV spectrophotometry. The DNA was stored at $-20^{\circ} \mathrm{C}$.

\section{Determination of amylose content}

Maize amylose content was measured by colorimetry (Morrison and Laignet, 1983; Martinez and Prodolliet, 1996) and near infrared reflectance spectroscopy (Orman and Schumann Jr., 1991; Ciurczak, 1995; Campbell et al., 1997).

\section{Cloning and sequence analysis of the $a e$ and $A e$ alleles}

Using the sequence of the ae alleles of maize (GenBank: AF072725), nine pairs of sequencing primers were designed using Primer Designer. The primers were synthesized by the Shanghai Sangon Company (Shanghai, China). The ae and Ae alleles were amplified from the leaf-derived genomic DNA of high-amylose inbred lines ae-1 and common maize inbred lines luyuan92, respectively. After electrophoresis detection, recycling and connection to carriers, we obtained full-length sequences of the two alleles, which illustrated their differences.

\section{Screening, verification and analysis of the ae allele molecular marker selection}

Based on the differences between the $a e$ and $A e$ alleles, five pairs of primers were designed. Three high-amylose maize inbred lines (ae-1, ae-2, and $\mathrm{S}_{3-4-5}$ ) and three common maize inbred lines (luyuan92, qi478, chang72) were polymerase chain reaction (PCR)-amplified to search for ae allele-specific molecular marker bands. Using the ae allele specific molecular marker primers, DNA from inbred lines and the combination groups was amplified to determine the utility of the ae allele molecular marker in marker-assisted selection (MAS). Reaction conditions for the degenerate primer pairs were initial denaturation for $5 \mathrm{~min}$ at $94^{\circ} \mathrm{C}$, followed by 35 cycles at $94^{\circ} \mathrm{C}$ for $45 \mathrm{~s}, 53^{\circ} \mathrm{C}$ for $45 \mathrm{~s}$, an extension of $72^{\circ} \mathrm{C}$ for $90 \mathrm{~s}$, and a final extension at $72^{\circ} \mathrm{C}$ for $10 \mathrm{~min}$. PCR analysis was performed on a Bio-Rad PTC-100 type PCR instrument.

\section{RESULTS}

\section{Identifying an ae alleles molecular marker}

\section{Cloning and sequence analysis}

After sequencing and splicing, we obtained full-length sequences of the ae and $A e$ alleles, which were analyzed for differences. The two alleles are homologous; the main differ- 
ences are single nucleotide polymorphisms, a single-base insertion/deletion, and three locations where the consecutive bases have been deleted (Figure 1). At bases 453-456 of this sequence, corresponding to the region between exon 9 and exon 10, the $a e$ allele has a four-base insertion compared to the $A e$ allele.

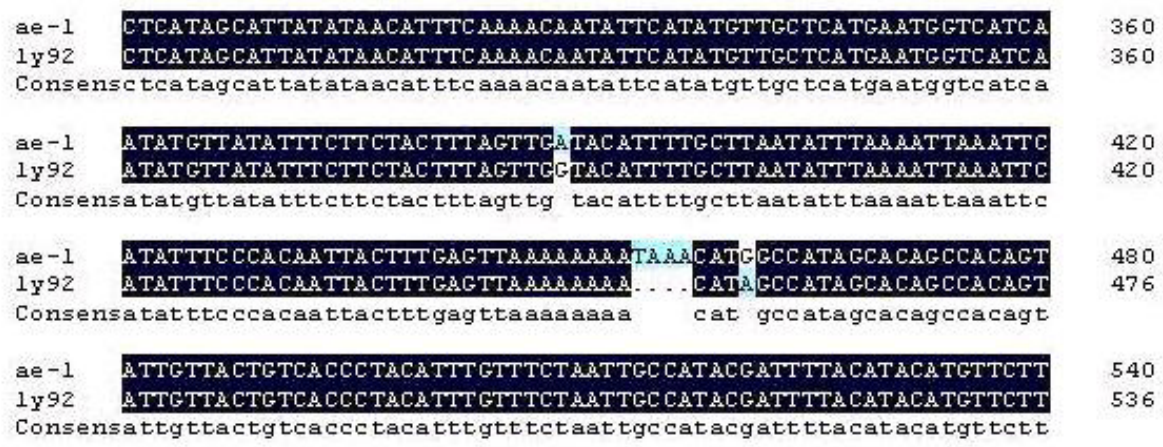

Figure 1. Partial sequence alignment between the ae and $A e$ alleles.

\section{Screening for molecular markers of the ae alleles}

Five pairs of primers were used to amplify fragments (Table 1). Only primer 1 (upstream primer: 5'-TCATCTTCTCACATTGGTCTTCC-3', downstream primer: 5'-GCTGTGCTATG GCCATGTTTAT-3') showed a polymorphism (Figure 2). The amplified regions of the ae and $A e$ alleles were at bases 6971-7467. We were unable to amplify a fragment from the common maize inbred lines, but we were able to amplify a 474-bp fragment from the high-amylose maize inbred lines. Consequently, we named this marker ae474.

\begin{tabular}{|c|c|c|}
\hline No. & Upstream 5, & Downstream 3' \\
\hline 1 & ССTCTTCTTAACTCGTAATGATC & TGCCTCTATATTGTCTGGCTAAC \\
\hline 2 & CTTCATAGTGTTGCTGGAAGGTC & GTACTTGATCCAGGCTGGAATTG \\
\hline 3 & TCATCTTCTCACATTGGTCTTCC & GCTGTGCTATGGCCATGTTTAT \\
\hline 4 & CACAGGCAAAGTGATGAAAC & TTATACACCCCAGGCTTTC \\
\hline 5 & TTCATGACATCTGATCACC & ATATAGAGAGGACAACGCAGC \\
\hline
\end{tabular}

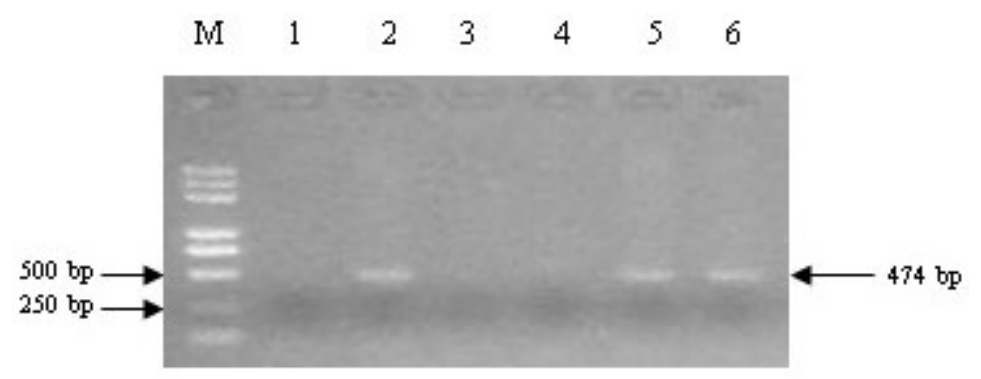

Figure 2. Amplification of high-amylose content maize and common maize with markers. $\mathrm{M}=\mathrm{DNA}$ marker (DL2000 plus). Lane 1 = luyuan92; lane 2 = ae-1; lane 3 = qi478; lane $4=$ chang72; lane $5=$ ae-2; lane $6=\mathrm{S}_{3-4-5}$. 


\section{Verification of the maize ae allele molecular marker and analysis of amylose content}

In 14 high-amylose maize inbred lines with the ae alleles, the specific ae 474 band was clearly amplified (Figure 3A). However, in 24 common maize inbred lines without the ae alleles, no band was amplified (Figure 3B). Because the ae 474 marker is stable and generates a clear band, it can be used as a dominant molecular marker linked to the ae alleles. The amylose content in 38 maize lines varied from $19.0 \%$ in cultivar 8129 to $58.2 \%$ in $\mathrm{S}_{4-25-2-1}$, which were negative and positive, respectively, for the ae474 marker (Table 2). All cultivars that were positive for ae 474 had substantially higher levels of amylose.
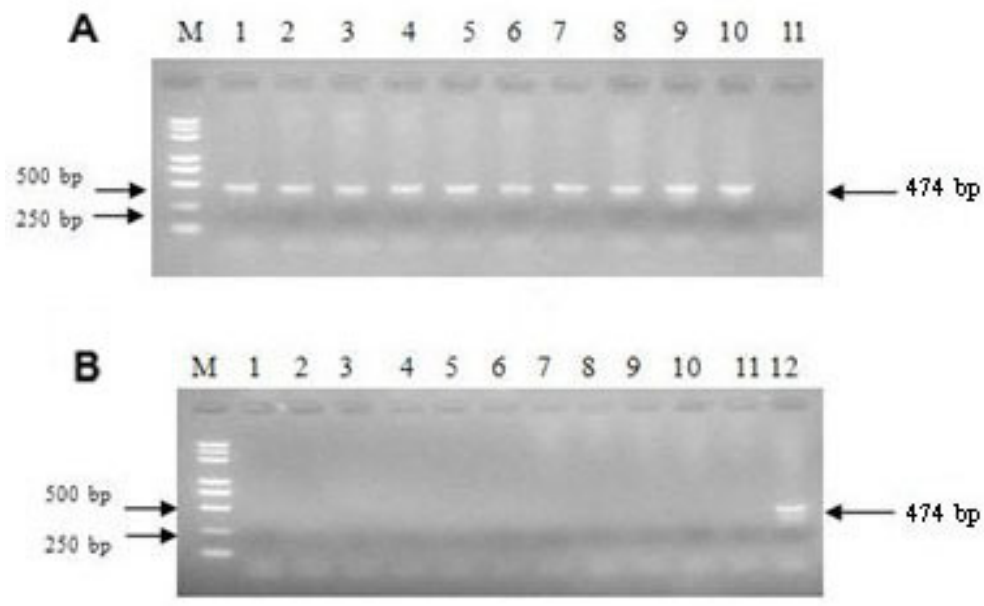

Figure 3. PCR amplification of maize inbred lines with markers. A. High-amylose content maize with markers. Lanes 1-10 = high-amylose maize; lane $11=\mathrm{CK}(-) ; \mathrm{M}=$ DNA marker (DL2000 plus). B. Common maize with markers. Lanes 1-11 = common maize; lane $12=\mathrm{CK}(+) ; \mathrm{M}=$ DNA marker (DL 2000 plus).

\begin{tabular}{|c|c|c|c|c|c|c|c|c|c|c|}
\hline \multirow{2}{*}{$\begin{array}{l}\text { No. } \\
1\end{array}$} & \multirow{2}{*}{$\begin{array}{c}\text { Cultivar } \\
\text { ae-1 }\end{array}$} & $\begin{array}{l}\text { Amylose molecular } \\
\text { marker }\end{array}$ & \multirow{2}{*}{$\begin{array}{r}\text { No. } \\
14\end{array}$} & \multirow{2}{*}{$\begin{array}{c}\text { Cultivar } \\
\text { W23 }\end{array}$} & \multicolumn{2}{|c|}{$\begin{array}{l}\text { Amylose molecular } \\
\text { marker }\end{array}$} & \multirow{2}{*}{$\begin{array}{l}\text { No. } \\
27\end{array}$} & \multirow{2}{*}{$\begin{array}{c}\text { Cultivar } \\
\text { qi478 }\end{array}$} & \multicolumn{2}{|c|}{$\begin{array}{c}\text { Amylose molecular } \\
\text { marker }\end{array}$} \\
\hline & & $57.8+$ & & & 53.4 & + & & & 22.2 & - \\
\hline 2 & ae-2 & $56.5+$ & 15 & luyuan92 & 24.2 & - & 28 & dan340di & 23.8 & - \\
\hline 3 & $\mathrm{~S}_{2-9-4}$ & $50.2+$ & 16 & 8129 & 19.0 & - & 29 & chang72 & 24.0 & - \\
\hline 4 & $\mathrm{~S}_{4-15-3-2}^{2-9-4}$ & $52.0+$ & 17 & w-3 & 21.5 & - & 30 & dan599 & 21.7 & - \\
\hline 5 & $\mathrm{~S}_{2-9-2-2-1}^{4-32}$ & $53.4+$ & 18 & $\operatorname{lian} 87$ & 19.8 & - & 31 & ye478 & 21.1 & - \\
\hline 6 & $\mathrm{~S}_{3-4-6-2}^{2-9-2-1}$ & $49.7+$ & 19 & qi319 & 23.2 & - & 32 & 78599xuan & 20.5 & - \\
\hline 7 & $\mathrm{~S}_{3-4-5}^{3-4-2}$ & $51.8+$ & 20 & zi06281 & 21.2 & - & 33 & liao88 & 19.5 & - \\
\hline 8 & $\mathrm{~S}_{4-21-4}^{3-4-5}$ & $54.2+$ & 21 & danyou & 24.6 & - & 34 & P138 & 24.0 & - \\
\hline 9 & $\mathrm{~S}_{4-25-2-1}^{4-4}$ & $58.2+$ & 22 & sb-16 & 20.5 & - & 35 & zheng58 & 21.8 & - \\
\hline 10 & $\mathrm{We}_{-4-2-2-1}$ & $56.0+$ & 23 & danyu 133 & 23.1 & - & 36 & K14 & 23.0 & - \\
\hline 11 & W64 & $50.7+$ & 24 & H178 & 24.9 & - & 37 & chang98 & 25.2 & - \\
\hline 12 & B37 & $53.1+$ & 25 & shen 137 & 20.7 & - & 38 & chang94-2 & 22.7 & - \\
\hline 13 & A619 & $49.7+$ & 26 & 414 & 27.0 & - & & & & \\
\hline
\end{tabular}

Nos. 1-14 are high-amylose maize cultivars of inbred lines; Nos. 15-38 are common maize cultivars of inbred lines; +: plant with ae474 marker; -: plant without ae474 marker. 


\section{Segregation of the ae allele molecular marker in offspring}

We randomly selected $90 \mathrm{~F}_{1}$ plants, $150 \mathrm{BC}_{1} \mathrm{~F}_{1}$ plants and $150 \mathrm{~F}_{2}$ plants from three crosses in each generation (30,50 and 50 plants per cross, respectively) between high-amylose and common maize cultivars. Offspring from all $\mathrm{F}_{1}$ crosses were positive for the ae marker (Table 3). The ae474 marker was present in the other two offspring types according to expected Mendelian ratios, as shown by the chi-square analysis $(\mathrm{P}<0.05)$ (Table 3, Figure 4). These data show that, using MAS, it is possible to distinguish between the AeAe genotype and the Aeaelaeae genotypes.

\begin{tabular}{|c|c|c|c|c|c|c|}
\hline Generation & Combination & Total plants & Positive plants & Negative plants & $\begin{array}{c}\text { Expected } \\
\text { pos:neg ratio }\end{array}$ & $\chi^{2}$ test \\
\hline \multirow{3}{*}{$\mathrm{F}_{1}$} & $\mathrm{We}_{-4-2} \times$ chang98 & 30 & 30 & 0 & & \\
\hline & $\mathrm{B} 37^{-42} \times \mathrm{qi} 478$ & 30 & 30 & 0 & & \\
\hline & $\mathrm{S}_{4-25-2-1} \times$ chang 72 & 30 & 30 & 0 & & \\
\hline \multirow[t]{3}{*}{$\mathrm{F}_{2}$} & $\mathrm{We}_{-4-2}^{4-2-1} \times$ chang 98 & 50 & 33 & 17 & $3: 1$ & $\chi^{2}=2.16, \mathrm{P}<0.05$ \\
\hline & $\mathrm{B} 37^{-42} \times \mathrm{qi} 478$ & 50 & 32 & 18 & $3: 1$ & $\chi^{2}=3.22, \mathrm{P}<0.05$ \\
\hline & $\mathrm{S}_{4-25-2-1} \times$ chang 72 & 50 & 35 & 15 & $3: 1$ & $\chi^{2}=0.67, \mathrm{P}<0.05$ \\
\hline \multirow[t]{3}{*}{$\mathrm{BC}_{1} \mathrm{~F}_{1}$} & $\mathrm{We}_{-4-2}^{4-2-1} /$ chang $98 \times$ chang 98 & 50 & 21 & 29 & $1: 1$ & $\chi^{2}=1.28, \mathrm{P}<0.05$ \\
\hline & $\mathrm{B} 37 / \mathrm{qi} 478 \times \mathrm{qi} 478$ & 50 & 21 & 29 & $1: 1$ & $\chi^{2}=1.28, \mathrm{P}<0.05$ \\
\hline & $\mathrm{S}_{4-25-2-1} /$ chang $72 \times$ chang 72 & 50 & 19 & 31 & $1: 1$ & $\chi^{2}=2.88, P<0.05$ \\
\hline
\end{tabular}

\section{A $\quad \begin{array}{llllllllllllll}\text { M } & 1 & 2 & 3 & 4 & 5 & 6 & 7 & 8 & 9 & 10 & 11 & 12\end{array}$}

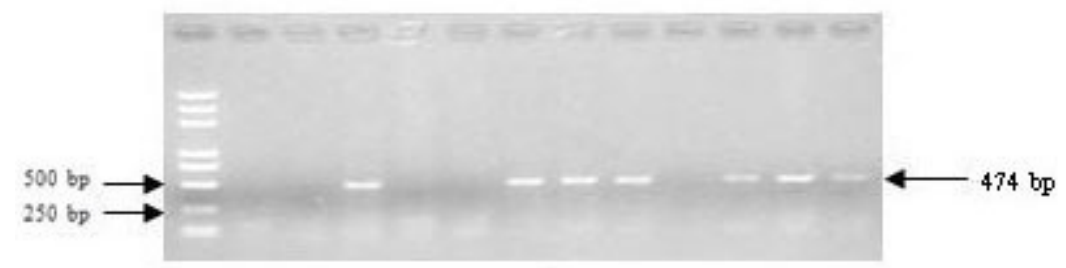

$\begin{array}{llllllllllllllll}\text { B } & \text { M } & 1 & 2 & 3 & 4 & 5 & 6 & 7 & 8 & 9 & 10 & 11 & 12 & 13\end{array}$

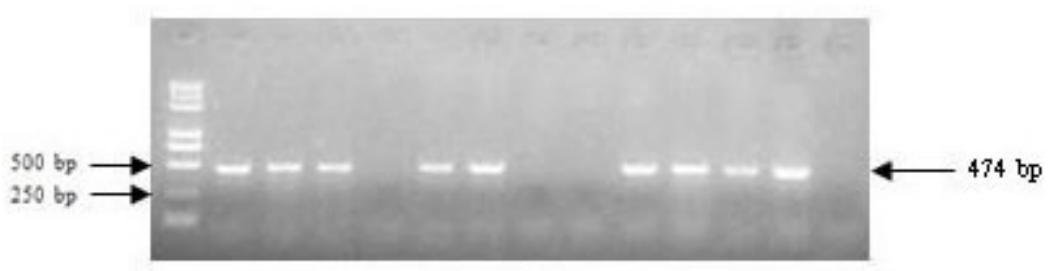

Figure 4. $P C R$ amplification in partial $\mathrm{BC}_{1} \mathrm{~F}_{1}$ and $\mathrm{F}_{2}$ generations with ae 474 molecular markers. A. PCR amplification of a partial $\mathrm{BC}_{1} \mathrm{~F}_{1}$ generation with ae 474 molecular markers. Lanes 1-12 $=\mathrm{BC}_{1} \mathrm{~F}_{1}$ generation plants; $\mathrm{M}=\mathrm{DNA}$ marker (DL2000 plus). B. PCR amplification in partial generation with ae474 molecular markers. Lanes 1-13= PCR amplification of the genome from $\mathrm{F}_{2}$ generations; $\mathrm{M}=$ DNA marker (DL 2000 plus). 


\section{Relationship between the ae allele molecular marker and amylose content}

We randomly selected 100 seeds from the $\mathrm{We}_{-4-2} \mathrm{x}$ chang98 combination for DNA extraction from the endosperm; an analysis was carried out for the presence of the ae474 marker and amylose content. Maize grains with $\geq 32.1 \%$ amylose amplified the ae 474 band, while those with less than $29.5 \%$ did not amplify the ae 474 band (Table 4 ). These statistics show that, with molecular MAS, we could obtain aeae, high-amylose genotypic materials. Only aeae homozygous seeds have an exceptionally high amylose content. While some of the seeds with less than $21.1 \%$ amylose were ae474-positive, those seeds are likely to have an Aeae genotype. We identified nine seeds of the $\mathrm{F}_{2}$ generation with $>38 \%$ amylose; they were all homozygous for $a e$.

\begin{tabular}{lcc}
\multicolumn{2}{c}{ Table 4. Relationship between the amylose content of $\mathrm{F}_{2}$ grain and the presence of the ae molecular marker. } \\
\hline Amylose content (\%) & Positive for $a e$ & Negative for $a e$ \\
\hline$<20.0$ & 0 & 6 \\
$20.1-23.0$ & 26 & 4 \\
$23.1-26.0$ & 31 & 4 \\
$26.1-29.0$ & 15 & 1 \\
$29.1-32.0$ & 1 & 0 \\
$32.1-35.0$ & 2 & 0 \\
$35.1-38.0$ & 3 & 0 \\
$38.1-41.0$ & 2 & 0 \\
$41.1-44.0$ & 4 & 0 \\
$>44.0$ & 84 & 16 \\
Total & & 0
\end{tabular}

\section{Analysis of the $a e$ allele molecular $\mathrm{MAS}$ in $\mathrm{BC}_{1} \mathrm{~F}_{1}$ and $\mathrm{BC}_{2} \mathrm{~F}_{1}$ generations}

We selected nine plants from the $\mathrm{BC}_{1} \mathrm{~F}_{1}$ and $\mathrm{BC}_{2} \mathrm{~F}_{1}$ generations of the $\mathrm{We}_{-4-2} \mathrm{x}$ chang98 cross, of which five plants yielded ae474 bands and four did not. After self-crossing, we obtained $\mathrm{BC}_{1} \mathrm{~F}_{2}$ and $\mathrm{BC}_{2} \mathrm{~F}_{2}$ generations, from each of which we chose 100 plants for ae dominant molecular marker detection (Figure 5, Table 5).

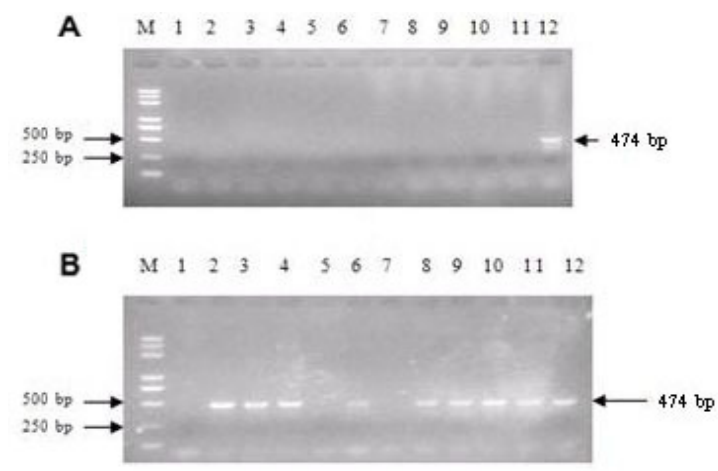

Figure 5. PCR amplification in $\mathrm{BC}_{2} \mathrm{~F}_{2}$ of the $\mathrm{BC}_{1} \mathrm{~F}_{1}$ generation with ae 474 markers. A. PCR amplification in $\mathrm{BC}_{2} \mathrm{~F}_{2}$ of the marked $\mathrm{BC}_{1} \mathrm{~F}_{1}$ generation with ae 474 markers. Lanes 1-11 $=\mathrm{BC}_{1} \mathrm{~F}_{2}$ generation plant; lane $12=\mathrm{CK}(+) ; \mathrm{M} \stackrel{2}{=}$ DNA marker (DL2000 plus). B. PCR amplification in $\mathrm{BC}_{2} \mathrm{~F}_{2}$ generation of unmarked $\mathrm{BC}_{1} \mathrm{~F}_{1}$ generation with ae 474 markers. Lanes 1-12 = $\mathrm{BC}_{1} \mathrm{~F}_{2}$ generation plant; $\mathrm{M}=\mathrm{DNA}$ marker (DL2000 plus). 


\begin{tabular}{|c|c|c|c|c|c|c|c|c|}
\hline Generation & Type & No. & Generation & $\begin{array}{c}\text { Total } \\
\text { plants }\end{array}$ & $\begin{array}{c}\text { No. of } \\
\text { positive }\end{array}$ & $\begin{array}{c}\text { No. of } \\
\text { negative }\end{array}$ & $\begin{array}{c}\text { Expected } \\
\text { pos:neg ratio }\end{array}$ & $\chi^{2}$ test \\
\hline \multirow{9}{*}{$\mathrm{BC}_{1} \mathrm{~F}_{1}$} & \multirow{4}{*}{$\begin{array}{c}\text { Negative } \\
\text { plants }\end{array}$} & 1 & \multirow{9}{*}{$\mathrm{BC}_{1} \mathrm{~F}_{2}$} & 100 & 0 & 100 & & \\
\hline & & 2 & & 100 & 0 & 100 & & \\
\hline & & 3 & & 100 & 0 & 100 & & \\
\hline & & 4 & & 100 & 0 & 100 & & \\
\hline & \multirow{5}{*}{$\begin{array}{c}\text { Positive } \\
\text { plants }\end{array}$} & 5 & & 100 & 70 & 30 & $3: 1$ & $\chi^{2}=1.33, \mathrm{P}<0.05$ \\
\hline & & 6 & & 100 & 67 & 33 & $3: 1$ & $\chi^{2}=3.41, \mathrm{P}<0.05$ \\
\hline & & 7 & & 100 & 67 & 33 & $3: 1$ & $\chi^{2}=3.41, \mathrm{P}<0.05$ \\
\hline & & 8 & & 100 & 69 & 31 & $3: 1$ & $\chi^{2}=1.92, \mathrm{P}<0.05$ \\
\hline & & 9 & & 100 & 68 & 32 & $3: 1$ & $\chi^{2}=2.61, \mathrm{P}<0.05$ \\
\hline \multirow{9}{*}{$\mathrm{BC}_{2} \mathrm{~F}_{1}$} & \multirow{4}{*}{$\begin{array}{c}\text { Negative } \\
\text { plants }\end{array}$} & 1 & \multirow[t]{9}{*}{$\mathrm{BC}_{2} \mathrm{~F}_{2}$} & 100 & 0 & 100 & & \\
\hline & & 2 & & 100 & 0 & 100 & & \\
\hline & & 3 & & 100 & 0 & 100 & & \\
\hline & & 4 & & 100 & 0 & 100 & & \\
\hline & & 5 & & 100 & 70 & 30 & $3: 1$ & $\chi^{2}=1.33, \mathrm{P}<0.05$ \\
\hline & \multirow{4}{*}{$\begin{array}{l}\text { Positive } \\
\text { plants }\end{array}$} & 6 & & 100 & 67 & 33 & $3: 1$ & $\chi^{2}=3.41, \mathrm{P}<0.05$ \\
\hline & & 7 & & 100 & 67 & 33 & $3: 1$ & $\chi^{2}=3.41, P<0.05$ \\
\hline & & 8 & & 100 & 69 & 31 & $3: 1$ & $\chi^{2}=1.92, P<0.05$ \\
\hline & & 9 & & 100 & 68 & 32 & $3: 1$ & $\chi^{2}=2.61, \mathrm{P}<0.05$ \\
\hline
\end{tabular}

From the $\mathrm{BC}_{1} \mathrm{~F}_{1}$ and $\mathrm{BC}_{2} \mathrm{~F}_{1}$ plants that were positive for the marker, we detected ae 474 bands in their $\mathrm{BC}_{1} \mathrm{~F}_{2}$ and $\mathrm{BC}_{2} \mathrm{~F}_{2}$ offspring. For those plant sets, which demonstrated some positive ae 474 bands, the ratio of positive to negative plants was $3: 1$. No ae474 bands were detected in the $\mathrm{BC}_{1} \mathrm{~F}_{2}$ and $\mathrm{BC}_{2} \mathrm{~F}_{2}$ offspring derived from the $\mathrm{BC}_{1} \mathrm{~F}_{1}$ and $\mathrm{BC}_{2} \mathrm{~F}_{1}$ plants that did not originally display the marker. These data confirm that we can obtain single plants with the ae alleles from offspring using MAS.

\section{Selection efficiency analysis of the ae allele molecular marker in backcross offspring}

Molecular MAS and non-marking random selection were respectively performed in the $\mathrm{BC}_{1} \mathrm{~F}_{1}$ and $\mathrm{BC}_{2} \mathrm{~F}_{1}$ generations of the $\mathrm{We}_{-4-2} \mathrm{x}$ chang 98 cross. The frequency of molecular marker detection and the selection efficiency of the ae alleles in the backcross offspring were observed and calculated. We chose 30 plants for molecular marker detection from each $\mathrm{BC}_{2} \mathrm{~F}_{1}$ and $\mathrm{BC}_{3} \mathrm{~F}_{1}$ generation (Table 6).

\begin{tabular}{lcr} 
Table 6. Efficiency analysis of ae allele molecular marker-assisted selection in backcross generations. & Non-marker selected \\
\hline Parameter & Marker selected & 30 \\
\hline Selective plants in $\mathrm{BC}_{1} \mathrm{~F}_{1}$ generation & 30 & 14 \\
No. of plants with marker in $\mathrm{BC}_{2} \mathrm{~F}_{1}$ generation & 30 & 46.7 \\
Selection efficiency (\%) & 100 & 53.3 \\
Efficiency improvement & 30 & 30 \\
Selective plants in $\mathrm{BC}_{2} \mathrm{~F}_{1}$ generation & 30 & 8 \\
No. of plants with marker in $\mathrm{BC}_{3} \mathrm{~F}_{1}$ generation & 100 & 26.7 \\
Selection efficiency (\%) & & 73.3 \\
Efficiency improvement & & \\
\hline
\end{tabular}

When MAS was used to identify the presence of the marker, the selection efficiency was $100 \%$ for both $\mathrm{BC}_{2} \mathrm{~F}_{1}$ and $\mathrm{BC}_{3} \mathrm{~F}_{1}$, a 53.3 and $73.3 \%$ improvement, respectively, over the efficiency of non-marker selection. These results confirm that the use of MAS in a backcross can significantly improve efficiency. 


\section{Rapid detection technology of the ae allele molecular marker}

To establish a quick and easy PCR detection method for the $a e$ allele molecular marker, seedling leaves were used for rapid extraction of DNA. By adding DNA-staining fluorescent dyes to the tube containing DNA for PCR amplification, we could directly observe the development of PCR products under UV light. Using this method, we could accurately identify positive and negative samples at an efficiency that was comparable to that of electrophoretic analysis. It is possible, therefore, to omit the electrophoretic analysis step, which will simplify MAS procedures and improve efficiency.

\section{DISCUSSION}

Selection of the most appropriate plants with desirable characteristics is an important step in breeding new crop cultivars (Van Berloo and Stam, 2001). Individual, or direct, selection, which focuses on agronomic traits that meet breeding objectives, is a phenotypic rather than genotypic selection technique (Ribaut and Betrán, 1999; Van Berloo and Stam, 2001; Francia et al., 2005). For the target gene, molecular marker-assisted breeding technology is a rapid and accurate method, providing a very effective tool for backcross breeding (Ribaut and Betrán, 1999; Frisch and Melchinger, 2005; Collard and Mackill, 2008). Several complex factors influence MAS efficiency, such as the distance between the marker and the target gene, where the marker is not part of the target gene. In our study, the marker is part of the target gene, thus eliminating the main disadvantage of MAS; the problems of linkage and exchange are also avoided (Lande and Thompson, 1990). Because this method can be used at the seedling stage, and DNA quality required for PCR is not high, it can significantly shorten the breeding cycle and improve selection efficiency. The ae alleles are recessive mutant alleles that promote a decrease in the quantity of starch converted from sugar. The resulting maize endosperm is dull and the grain shows a certain degree of shrinkage. These phenotypic traits are distinctive for plants that are homozygous for ae. Its stability, however, is low and therefore using this homozygous phenotype to select the ae alleles is not efficient.

In this study, an ae allele-specific molecular marker was acquired that contained a 4-bp nucleotide deletion, lying in an intron between exons 9 and 10 of the ae and Ae alleles, making it completely linked to the ae alleles. Although the marker is dominant, it cannot distinguish between the Aeae and aeae genotypes. The marker has high reliability and efficiency, and the PCR product can be identified visually in a micro-tube; therefore, it is simple and rapid. With the aid of this marker, high-amylose materials can be selected at a variety of life stages, from harvest to seedlings. This is particularly true when the target is the Aeae genotype in backcross breeding. The high amylose maize backcross breeding process can therefore be accelerated.

Studies have shown that the interaction(s) between ae and other starch mutant alleles (e.g., du and su) may significantly alter amylose content (Yun and Matheson, 1993; Wang et al., 1993). Vineyard et al. (1958) reported that the level of amylose in hybrid offspring ranged from 36.5 to $64.9 \%$ in cross tests between 135 different inbred lines and a common ae donor. The substantial variability in amylose content of hybrid offspring was likely due to interactions between different "modified genes" of the germplasm and the ae alleles. The presence of the ae alleles itself, therefore, is no guarantee of exceptionally elevated amylose since the presence of other genes may cause amylose to vary from $50 \%$ to as much as $85 \%$. 
The combination of $a e$ and modified genes should be taken into consideration in the breeding process. More modified genes are needed if a consistent amylose content of $75 \%$ or more is to be achieved. Only in ae homozygous loci does the accumulation of modified genes have a selective effect.

In the process of high-amylose maize backcross breeding, the initial step is to choose the desired ae genotype - Aeae - using the ae 474 molecular marker. Self-crossing is conducted every two or three generations, which greatly reduces costs and improves the selection efficiency. Using half seed PCR and rapid amylose measurement, it is possible to screen highamylose seeds for $a e$-modified genes. Using cross-breeding, we can directly select high-amylose seeds from the identified Aeae and aeae genotypes, to obtain aeae plants and additional modified genes.

\section{ACKNOWLEDGMENTS}

Research supported by the National High Technology Research and Development Program ("863” Program) of China (\#2006AA10Z1B4). We thank members of the Key Laboratory of Biomass Improvement and Conversion of Anhui province and Yan Liu for assistance in these experiments.

\section{REFERENCES}

Campbell MR, Brumm TJ and Glover DV (1997). Whole grain amylase analysis in maize using near-infrared transmittance spectroscopy. Cereal Chem. 74: 300-303.

Ciurczak EW (1995). Use of near infrared spectroscopy in cereal products. Food Test. Anal. 5: 35-39.

Collard BC and Mackill DJ (2008). Marker-assisted selection: an approach for precision plant breeding in the twenty-first century. Philos. Trans. R. Soc. Lond. B. Biol. Sci. 363: 557-572.

Fergason V (1994). Specialty Corns. CRC Press, Boca Raton.

Fisher DK, Gao M, Kim KN, Boyer CD, et al. (1996). Allelic analysis of the maize amylose-extender locus suggests that independent genes encode starch-branching enzymes IIa and IIb. Plant Physiol. 110: 611-619.

Francia E, Tacconi G, Crosatti C, Barabaschi D, et al. (2005). Marker assisted selection in crop plants. Plant Cell Tissue Organ Cult. 82: 317-342.

Frisch M and Melchinger AE (2005). Selection theory for marker-assisted backcrossing. Genetics 170: 909-917.

Kim KN, Fisher DK, Gao M and Guiltinan MJ (1998). Molecular cloning and characterization of the Amylose-Extender gene encoding starch branching enzyme IIB in maize. Plant Mol. Biol. 38: 945-956.

Lande R and Thompson R (1990). Efficiency of marker-assisted selection in the improvement of quantitative traits. Genetics 124: 743-756.

Leterrier M, Holappa LD, Broglie KE and Beckles DM (2008). Cloning, characterisation and comparative analysis of a starch synthase IV gene in wheat: functional and evolutionary implications. BMC Plant Biol. 8: 98.

Martinez C and Prodolliet J (1996). Determination of amylose in cereal and non-cereal starches by a colorimetric assay: collaborative study. Starch 48: 81-85.

Morrison WR and Laignet B (1983). An improved colorimetric procedure for determining apparent and total amylose in cereal and other starches. J. Cereal Sci. 1: 9-20.

Nishi A, Nakamura Y, Tanaka N and Satoh H (2001). Biochemical and genetic analysis of the effects of amylose-extender mutation in rice endosperm. Plant Physiol. 127: 459-472.

Orman BA and Schumann RA Jr (1991). Comparison of near-infrared spectroscopy calibration methods for the prediction of protein, oil, and starch in maize grain. J. Agric. Food Chem. 39: 883-886.

Ribaut JM and Betrán J (1999). Single large-scale marker-assisted selection (SLS-MAS). Mol. Breed. 5: 531-541.

Rutenberg MW and Solarek D (1984). Starch: Chemistry and Technology. 2nd edn. Academic Press, Orlando.

Saghai Maroof MA, Biyashev RM, Yang GP, Zhang Q, et al. (1994). Extraordinarily polymorphic microsatellite DNA in barley: species diversity, chromosomal locations, and population dynamics. Proc. Natl. Acad. Sci. U. S. A. 91: $5466-5470$. 
Seetharaman K, Tziotis A, Borras F, White PJ, et al. (2001). Thermal and functional characterization of starch from Argentinean corn. Cereal Chem. 78: 379-386.

Smith AM, Denyer K and Martin C (1997). The synthesis of the starch granule. Annu. Rev. Plant Physiol. Plant Mol. Biol. 48: 67-87.

Sun C, Sathish P, Ahlandsberg S and Jansson C (1998). The two genes encoding starch-branching enzymes IIa and IIb are differentially expressed in barley. Plant Physiol. 118: 37-49.

Van Berloo R and Stam P (2001). Simultaneous marker-assisted selection for multiple traits in autogamous crops. Theor. Appl. Genet. 102: 1107-1112.

Vineyard ML, Bear RP, MacMasters MM and Deatherage WL (1958). Development of "Amylosemaize" - corn hybrids with high amylose starch. Agron. J. 50: 595-598.

Wang YJ, White P, Pollak L and Jane J (1993). Characterization of starch structures of 17 maize endosperm mutant genotypes with Oh43 inbred line background. Cereal Chem. 70: 171-179.

Whistler RL (1958). Amylose development and progress. Chemurgic Dig. 17: 38.

Wu Y, Campbell M, Yen Y, Wicks Z III, et al. (2009). Genetic analysis of high amylose content in maize (Zea mays L.) using a triploid endosperm model. Euphytica 166: 155-164.

Yun SH and Matheson NK (1993). Structures of the amylopectins of waxy, normal, amylose-extender, and wx:ae genotypes and of the phytoglycogen of maize. Carbohydr. Res. 243: 307-321. 